\section{The Effect of Repetitious Concussions on Cognitive Functions in Rats}

\section{Ratlarda Tekrarlayan Konküzyonların Bilișsel Fonksiyonlar Üzerine Etkisi}

\begin{abstract}
AIM: In this study, we aimed to investigate the effect of repetitious concussions on the spatial learning and memory function in rats.

MATERIAL and METHODS: 46 adult, male Sprague-Dawley rats were assigned to three homogenous groups by stratified random sampling according to their basal performance during the first four days of the Morris water maze (MWM), as Control $(n=10)$, Sham $(n=10)$ and Concussion $(n=26)$ groups.

On the 12th day, the MWM experiment was repeated to evaluate the memory function. Rats in the concussion group were then subjected to the first head trauma. Some of the trauma-applied rats were sacrificed for histopathological examination 4 hours $(n=4)$ and 24 hours $(n=3)$ after the trauma. The spatial memory function of the rest of the rats was re-evaluated by MWM on the 20th day. Some of the rats were then subjected to the second head trauma $(n=13)$, four of which were then sacrificed at the $4^{\text {th }}$ hour, and three of which were sacrificed at the $24^{\text {th }}$ hour. On the $27^{\text {th }}$ day, six rats that had received single concussion and the remaining six that had received two concussions were re-evaluated for retention development by the third MWM experiment.

RESULTS: Escape latency curves showed a decrease in Sham and Control groups on the $20^{\text {th }}$ and $27^{\text {th }}$ days, and an increase in concussion group on the $20^{\text {th }}$ day but no statistical significance was found between the groups.

CONCLUSION: Repetitious concussions did not significantly affect spatial learning-memory functions in rats, and may lead to a counter-adaptive mechanism against concussive injury.

KEYWORDS: Repetitious concussion, Head trauma, Concussion
\end{abstract}

\section{ÖZ}

AMAÇ: Bu çalışmada, sıçanlarda tekrarlayan konküzyonların uzaysal öğrenmebellek işlevine olan etkisinin araştırılması amaçlandı.

YÖNTEM ve GEREÇ: Bu çalışmada kırk altı adet erişkin, erkek Sprague-Dawley sıçan kullanıldı. Sıçanlar, ilk 4 gün boyunca Morris su labirenti (MSL) aracılığıyla saptanan bazal uzaysal öğrenme düzeyleri (kaçış latansı) esas alınarak tabakalı randomize örnekleme ile homojen gruplara ayrıldılar: 1- Kontrol ( $n=10), 2$ - Sham $(\mathrm{n}=10), 3-K o n k u ̈ z y o n(\mathrm{n}=26)$. MSL deneyi 12. günde, retansiyon (bellek) gelişiminin test edilmesi amacıyla tekrarlandı. Ardından konküzyon grubundaki 26 hayvana ilk kafa travması uygulandı. Kafa travmasını takiben sıçanların dördü dört saat, üçü de 24 saat sonra sakrifiye edildiler. 20. günde MSL deneyi tekrar edildi. Daha sonra konküzyon grubundaki 13 hayvana ikinci kez kafa travması uygulandı. Bunlardan dördü dört saat, üçü de 24 saat sonra sakrifiye edildi. Ardından, tek konküzyon uygulanmış olan altı sıçan ile iki konküzyon uygulanmış olan altı sıçan 27. günde üçüncü retansiyon deneyi ile tekrar değerlendirildi.

BULGULAR: Kaçış latans eğrileri 20. ve 27. günlerde sham ve kontrol grubunda azalma eğiliminde iken 20. günde konküzyon grubunda artma eğiliminde idi. Ancak gruplar arasında istatistiksel olarak anlamlı farklılık saptanmadı.

SONUÇ: Uygulanan deneysel modele göre, tekrarlayan kafa travmaları sıçanlarda uzaysal ögrenme-bellek işlevini belirgin biçimde etkilememiştir.

ANAHTAR SÖZCÜKLER: Tekrarlayan konküzyon, Kafa travması, Konküzyon
Doga GURKANLAR ${ }^{1}$

Illker COVEN²

Remzi ERDEM ${ }^{3}$

Ozlem OZEN ${ }^{4}$

Sebnem KOSDAK ${ }^{5}$

Cem YILMAZ ${ }^{6}$

Engin YUCEL ${ }^{7}$

Nur ALTINORS ${ }^{8}$

1,2,6,7,8 Başkent University, Faculty of Medicine, Department of Neurosurgery, Ankara, Turkey

3,5 Başkent University, Faculty of Medicine, Department of Pharmacology, Ankara, Turkey

4 Başkent University, Faculty of Medicine, Department of Pathology, Ankara, Turkey

Received : 25.04.2010 Accepted : 30.04 .2010

Correspondence address: Doga GURKANLAR Baskent University, School of Medicine, Department of Neurosurgery, Alanya, TURKEY

Phone : +90 2425112511

Fax : : +90 2525115563

E-mail : dgurkanlar2000@yahoo.co.uk 


\section{INTRODUCTION}

Concussion is defined as a trauma-induced complex pathophysiological process affecting the brain that may be associated with rapid onset of short lived neurological dysfunctions such as transient loss of consciousness, retrograde amnesia, disorientation and attention deficits $(4,9,19,23,33,36)$.

Sports and recreational activities contribute to approximately $10 \%$ of all mild injuries with an estimated annual incidence of 300.000 cases (25). These individuals are at high risk of experiencing a second traumatic brain injury (TBI) (38) and the frontal lobe is found to be the most common site of focal lesions after mild traumatic injury (10).

Laboratory studies indicate that concussion may cause transient functional impairments due to pathogenic events such as excitatory amino acid release, alterations in regional cerebral blood flow and metabolism and ionic dyshomeostasis, and these events may sensitize the brain to a second TBI $(15,18,22,39)$. It was also reported that players who sustained a concussion were three times more likely to have a second concussion (17) and athletes with multiple concussions might have cumulative effects (21).

Reproducible laboratory evidence on the duration of vulnerability of brain after a single concussion seems to be lacking (16), and there is still no consensus on the management strategies of concussions that occur during contact sports due to the lack of prospective data correlating outcome to the initial signs and symptoms of the injury $(7,8,12)$.

Although some authors suggested that multiple concussions lead to impairment in cognitive functions $(13,24,26,31,32)$, Longhi et al, observed no deficits when the injury interval was extended to seven days (29).

The aim of the present study was to evaluate the effects of repetitious concussions on cognitive functions, in particular on the process of memory development and the extent of cortical and hippocampal cellular abnormalities in rats. Our objective was to investigate the above-mentioned functional effect, if any, by evaluating memory function in terms of retention development by using the Morris water maze, a tool for testing the spatial learning and memory function in rodents.
We hypothesized that repetitious concussions would diminish the deleterious effect of concussive injury on memory formation in rats.

\section{MATERIALS and METHOD}

\section{Animals}

The present study was started after having the project proposal approved by the Başkent University Local Ethical Committee on Research in Experimental Animals (approval date and number of the project; August 27, 2008 and DA08/16, respectively). Fortysix adult Sprague-Dawley rats $(300 \pm 50 \mathrm{~g}$, male) were used in the study. All animals had free access to food (standard rat chow) and drink (regular tap water) throughout the study.

Acclimatization, preliminary training and initial experimental groups

After having the animals acclimatized to the environment by keeping them at the animal facility without performing any experimental procedure for 1 week, the experimental set up was introduced to the animals through a set of training sessions for three consecutive days. During this period, each rat was put in the Morris water maze (MWM) and allowed to swim for 15 seconds daily, as if it was a shortened version of the actual experiment, but with the maze lacking the escape platform. Data were neither collected nor evaluated during the preliminary training period.

\section{Morris Water Maze (MWM)}

MWM, an established method for evaluating spatial learning and memory development in rodents, was used to evaluate the effect of repetitious concussions on cognitive functions, particularly on memory development (34). A blackpainted, water-filled, $120 \mathrm{~cm}$ width $\times 60 \mathrm{~cm}$ height polycarbon cylindrical tank placed in the middle of a cubical room $(3 \times 3 \times 2.5 \mathrm{~m})$ was used for the MWM experiments. A basic directional nomenclature was used to emphasize the localization of the walls, i.e., South, North, East and West. Several permanent cues for orientation were permanently placed on the walls centrally. Two identical blue-colored rectangles of $35 \times 50 \mathrm{~cm}$ size each, one yellow-colored circle of $48 \mathrm{~cm}$ diameter and three identical red-colored triangles of $44 \times 38 \mathrm{~cm}$ size each were placed on the West, East and North walls, respectively. The South wall was intentionally kept blank. The temperature of the water in the tank was kept constant at $22 \pm 1^{\circ} \mathrm{C}$. 
The level of water surface was kept $10 \mathrm{~cm}$ below the top of the tank. An escape platform of circular shape ( $9 \mathrm{~cm}$ diameter) was placed $1 \mathrm{~cm}$ below the water surface at a certain location.

MWM procedure and evaluation of the spatial learning and memory process

Each rat was put in the water gently while facing the wall, at every direction each day, for four consecutive days. Each rat was given a time of maximal $120 \mathrm{sec}$ at each direction to find the escape platform. The duration to find the platform was called the escape latency. If any rat succeeded to escape, it was allowed to stay on the platform for 10 additional seconds before taking it out of the tank, in order to eliminate the possibility of coincidental success and to help the rat to recognize the orientation cues. If the animal failed to find and step on the escape platform, it was guided to the platform by gentle touches and was let to stay there for $10 \mathrm{sec}$. The observer never entered the MWM room during the session unless the latter case happened, in which case he left the room after helping the rat step on the platform. The observation, data acquisition and evaluation procedure were performed by the customized software for animated image analysis via a computer connected to a webcam placed at the centre of the ceiling of the MWM room. The Mat-Lab based custom software for MWM experiments was developed by the Department of Biomedical Engineering at Baskent University, Faculty of Engineering, in order to evaluate the escape latency (sec), motor activity (swimming speed; $\mathrm{cm} / \mathrm{sec}$ ), cumulative distance swum ( $\mathrm{cm})$, and momentary distance to the escape platform $(\mathrm{cm})$. The mean of the data from four directions each day was taken as the daily average of the above mentioned parameters and used to form cognitive function-time curves.

\section{Experimental protocol}

After having obtained the basal learning (escape latency) curves through days 1 to 4 , the rats were initially assigned by stratified random sampling due to their basal cognitive performance to three groups; 1. Control $(n=10), 2$. Sham $(n=10)$, and 3. Concussion $(n=26)$, with lower inter-group but higher intra-group variations. On the $12^{\text {th }}$ day, the MWM experiment was repeated to obtain retention (memory) data. The 26 animals in the Concussion group were then subjected to the first head trauma, four of which were sacrificed 4 hours, and three of which were sacrificed 24 hours, respectively, after the trauma for histopathological examination. On the $20^{\text {th }}$ day, the MWM experiment was repeated. Afterwards 13 animals from the Concussion group were subjected to the second head trauma, four of which were then sacrificed 4 hours, and three of which were sacrificed 24 hours, respectively, after the second concussion for histopathological examination. On the $27^{\text {th }}$ day, six rats receiving a single concussion and the remaining six with two concussions were re-evaluated by the third retention experiment.

The Sham group was subjected to all of the procedures performed in the Concussion group except for the trauma process, while Control animals were kept naive to any procedure throughout the study.

\section{Surgical Procedure}

Rats were anesthetized with intramuscular ketamine $45 \mathrm{mg} / \mathrm{kg}$ and xylazin $7 \mathrm{mg} / \mathrm{kg}$. The head of each animal was fixed in a stereotactic frame to prevent movement. A midline skin incision was performed to expose the calvarium. We used a silicon tip impactor driven by a pneumatic piston. The impounder was positioned at $90^{\circ}$ and driven at 5.0 $\mathrm{m} / \mathrm{s}$ to a depth of $3 \mathrm{~mm}$ farther than the zero point causing a non-penetrating concussive blow to the head with no skull fracture. After the compact brain injury the incision was closed with a 4.0 silk suture. The animals then were returned to their cages and allowed to recover from anesthesia. The neurological status of each animal was observed during the recovery.

\section{Tissue fixation and Histopathology}

Following the last controlled cortical impact brain injury, animals were reanesthetized intramuscular ketamine $45 \mathrm{mg} / \mathrm{kg}$ and xylazin $7 \mathrm{mg} / \mathrm{kg}$ and perfused intracardially with heparinized saline solution (1000 units/l) by transthoracic canulation of the left ventricle followed by fixative ( $4 \%$ paraformaldehyde in $0.1 \mathrm{M}$ phosphate buffer, $\mathrm{PH}$ : 7.4 ). The scalp of each animal was opened under the operating microscope and skulls were observed for the possibility of any skull fracture. The brains were then removed and stored in a fixative for $4 \mathrm{~h}$ at $4^{\circ} \mathrm{C}$, and then stored in 30\% sucrose in phosphatebuffered saline (PBS) at $4^{\circ} \mathrm{C}$. After sucrose infiltration, the brains were frozen in $-20^{\circ} \mathrm{C}$ isopentane. Fortymicrometer thick coronal serial sections from 1.1 
$\mathrm{mm}$ anterior to $2.8 \mathrm{~mm}$ posterior to the bregma were cut on a sliding microtome. Brain sections from all animals were stained by routine hematoxylin-eosin (H\&E) procedure.

\section{Statistical Analysis}

All data were expressed as mean \pm S.E.M. Twoway ANOVA (time-procedure) was performed to determine the difference among groups. If any statistical difference was determined postHoc Bonferroni's test was performed for further evaluation. Confidence interval was taken as $95 \%$ and $P$ values $<0,05$ were accepted as statistically significant.

\section{RESULTS}

\section{Cognitive performance}

\section{i. Basal learning and retention development}

An improvement in learning performance, as expected, was apparently observed according to the to the escape latency values. Through days 1 to 4 , the daily average values for escape latency were as follows: $39.6 \pm 2.3 \mathrm{sec}, 19.8 \pm 1.5 \mathrm{sec}, 17.1 \pm 1.5 \mathrm{sec}$ and $13.4 \pm 1.3 \mathrm{sec}$, respectively (Figure 1). The average latency value obtained on the $12^{\text {th }}$ day $(13.2 \pm 1.1 \mathrm{sec})$ elicited no retention development, in comparison with the fourth day average $(13.4 \pm 1,3 \mathrm{sec})$. We observed that escape latency curves showed a tendency to decrease in the Sham and Control groups on days 20 and 27, and a tendency to increase in the Concussion group on the $20^{\text {th }}$ day but no statistical significance was determined between the groups (Figure 1). On the $20^{\text {th }}$ day the latency values of the groups were in a narrow range $(14.0 \pm 1.5 \mathrm{sec} ; 13.2 \pm 2.5 \mathrm{sec} ; 12.3 \pm 1.1$ $\mathrm{sec}$ ), while on the $27^{\text {th }}$ day the deleterious effect of repetitious concussion on retention became apparent, although none of the differences was significant $(13.2 \pm 2.2 \mathrm{sec} ; 11.8 \pm 1.5 \mathrm{sec} ; 9.6 \pm 1.4 \mathrm{sec}$ ) (Figure 1)

ii. The effect of concussion(s) on the locomotor activity in the long term

Concussion(s) did not produce any significant effect on the parameters evaluating locomotor activity, such as swimming speed, cumulative distance swum and momentary distance to the escape platform (data not shown).

\section{Histopathology}

The formalin-fixed, paraffin embedded and H\&E stained sections of brain tissues showed no specific morphological evidence of injury in all levels (Figure 2A). Only a small amount of edema was observed, particularly in the cortical areas and thalamus of animals subjected to cerebral brain injury (CBI) (Figure 2B).

\section{DISCUSSION}

The diagnosis and management of repetitious concussions have been debated in neurosurgery. Although some authors suggested that repetitious concussions may lead to cumulative effects $(8,13,21$, $24,26,31,3237)$, others reported that individuals may have an adaptive capability (20) and can be managed conservatively with rest $(29,35)$.

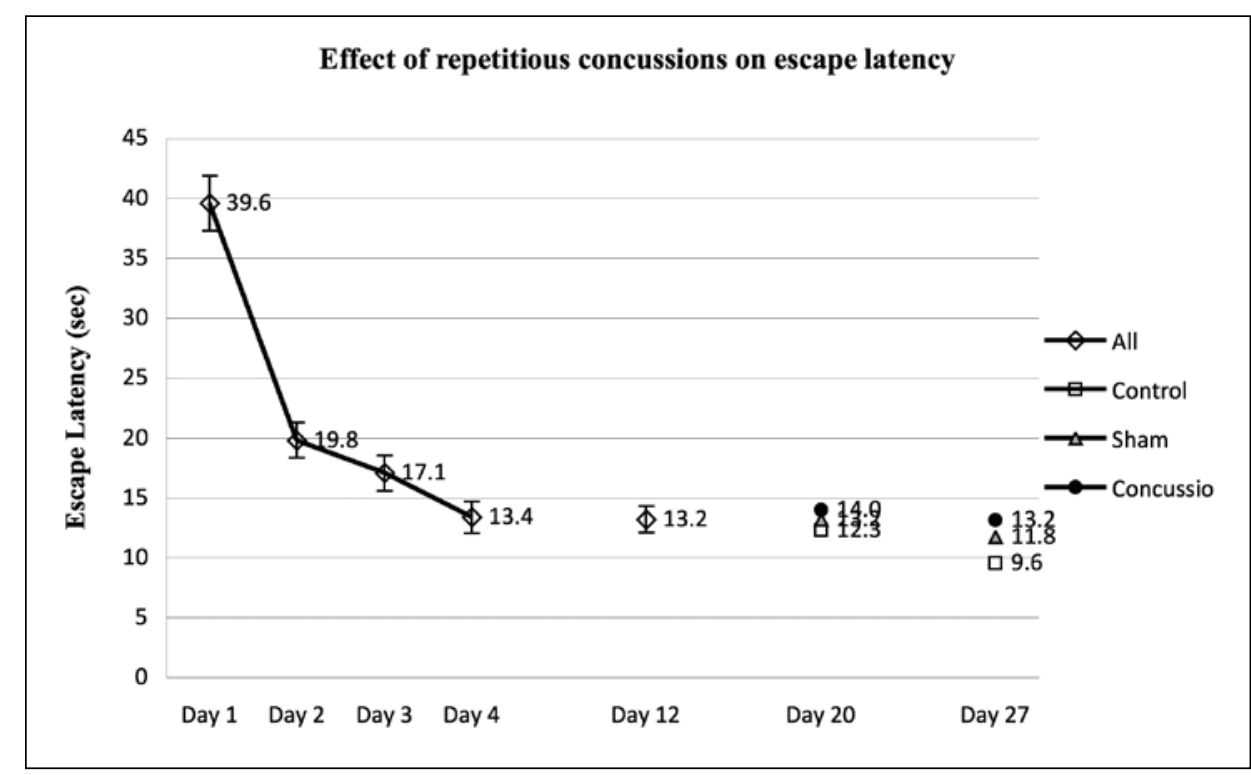

Figure 1: Effect of repetitious concussions on escape latency. 

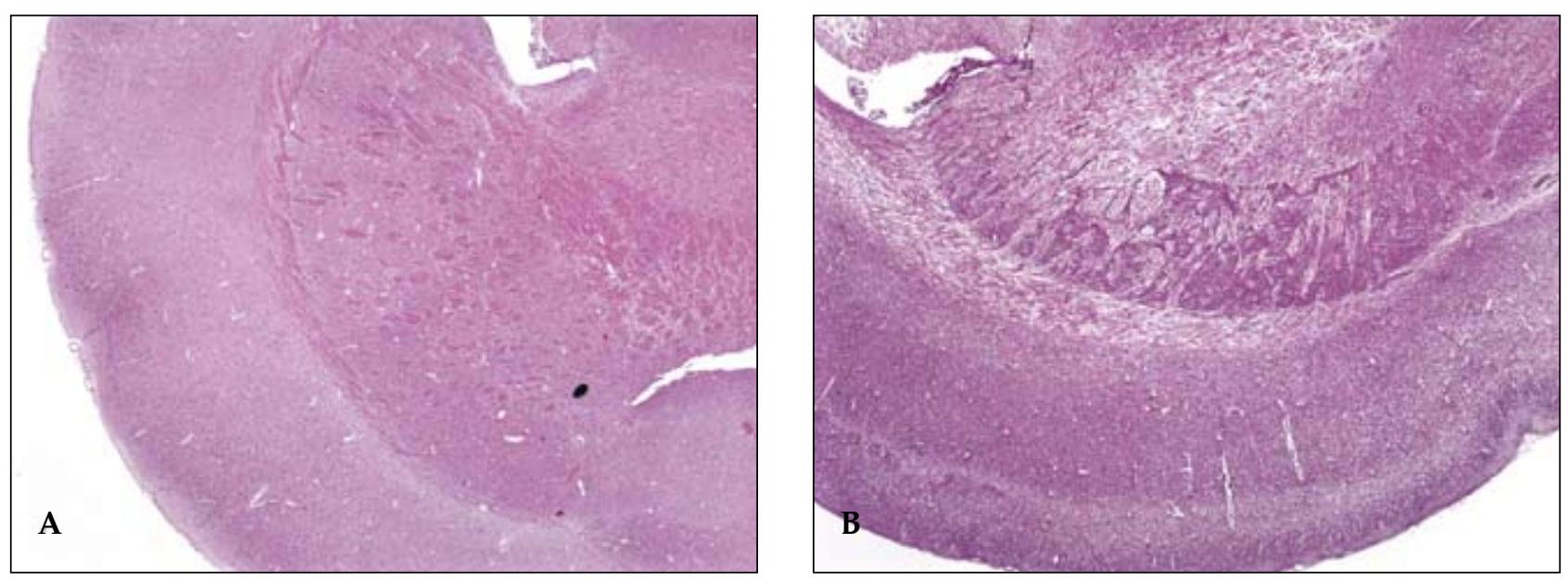

Figure 2: (A) Histopathology of brain tissues showed no specific morphologic evidence of injury at all levels (HEE, 40X), (B) A small amount of edema was observed particularly in the cortical areas and thalamus of animals subjected to CBI.

Laurer et al found that the brain was more vulnerable to second insult if the second injury occurred within 24 hours after the first mild head trauma (26). However, Longhi et al, reported that the vulnerability after the first cerebral brain injury (CBI) was transient and lasted one week after the first concussion and the occurrence of a second concussion does not produce additional cognitive and / or neurological motor alterations (29). Longhi et al. also stated that animals subjected to two seizures after repetitious CBI had significantly impaired cognitive functions such as learning, probably due to the additional damage as a result of excitotoxicity involving the hippocampus $(29,40)$, but none of our animals had a seizure. DeFord et al. showed that four mild impacts to the brain, produced at intervals of 24 hours, led to learning deficits at 3 days after the last impact compared with mice receiving a single injury, suggesting that there is a cumulative effect of repetitious injuries on learning ability (11). Nevertheless, Hugh et al. reported that compact cerebral injury (CCI) in mice caused a marked decrease in immunolabeling for high molecular weight neurofilaments (NFH) in the ipsilateral cortex, hippocampal CA1 and CA3, dentate gyrus, and hilus within minutes and demonstrated that the partial recovery of NFH immunoreactivity following focal mild head trauma was apparent in the ipsilateral cortex and the hippocampal CA 3 regions by 24 hours, indicating a potential adaptive capability of neurons (20). The recovery of neurofilaments (NF) after CCI is similar to observations in other animal models of traumatic brain injury of a transient loss of MAP-2 in vulnerable brain regions $(5,14,28,29)$.
It is very difficult to describe the diagnosis and management of sport concussions due to the repetitious concussive injuries. The results in the few retrospective analyses are conflicting. While one study found that a history of two or more prior concussions predisposed athletes to significantly reduced cognitive function (7), another study found no postconcussion neurophysiological test differences between athletes who reported multiple prior concussions (30). Another study suggested that a single concussive brain injury (CBI) was not associated with cognitive impairment (29). Regardless of these conflicting data, the athlete must be completely symptom-free at rest or during exercise before resuming sports activity (8).

Our results proved that repetitious concussions produced at least at one-week intervals did not affect the baseline performance levels of the rats. No cumulative effect was observed as stated by Laurer, Longhi, DeFord and Hugh et al. as well. Performances following subsequent $\mathrm{CBI}$ were different from the initial performance levels obtained during the training period but lacking statistical significance.

All current concussion grading parameters evaluate the athlete's return to sport participation, at least in part, within the context of the number of prior concussions that the athlete has sustained $(1,3,7,23)$, and guidelines have been developed to try to establish the safe interval between a concussion and the subsequent return to play $(2,6,36)$. Pellman et al. recommended managing single and repeated concussions conservatively with rest and more than $50 \%$ of the players with repeated injuries returned 
to play within a day (35). The latter is in accordance with the main finding of our study.

\section{CONCLUSION}

In light of the findings of the present study, we suggest that repetitious concussions do not affect cognitive functions significantly and may lead to a counter-adaptive mechanism against concussive injury in rats.

\section{Acknowledgements}

The authors wish to thank Ass. Prof. Dr. Bulend Yilmaz, Bugra Bozkurt, from the Department of BioMedical Engineering at Baskent University, Faculty of Engineering, and Fatma Kocak, for her technical assistance during the MWM experiments.

This study financially supported by the Baskent University Research fund.

\section{REFERENCES}

1. American Congress of Rehabilitation Medicine, Head Injury Interdisciplinary Special Interest Group: Definition of mild traumatic brain injury. J Head Trauma Rehabil 8: 86-87, 1993

2. Aubry M, Cantu R, DvorakJ, Graf-Baumann T, Johnston K, Kelly J, Lovell M, McCrory P, Meeuwisse W, Schamasch P: Summary and agreement statement of the First International Conference on Concussion in Sport, Vienna 2001: Recommendations for the improvement of safety and health of athletes who may suffer concussive injuries-Concussion in Sport Group. Brit J Sports Med 36:6-10, 2002

3. Bailes JE, Cantu RC: Head injury in athletes. Neurosurgery 48 : 26-46, 2001

4. Blostein PA, Jones SJ, Bubshler CM, Vandongen S. Cognitive screening in mild traumatic brain injuries; analysis of the neurobehavioral cognitive status examination when utilized duringinitial trauma hospitalization. J Neurotrauma 14: 171177,1997

5. Caner H, Can A, Atalay B, Erdogan B, Albayrak AH, Kilinc $\mathrm{K}$, Bavbek M, Altinors N: Early effects of mild brain trauma on the cytoskeletal proteins neurofilament160 and MAP2, and the preventive effects of mexilitine.Acta Neurochir (Wien) 146(6):611-621, 2004

6. Cantu RC: Return to play guidelines after a head injury. Clin Sports Med 17:45-60, 1998

7. Collins MW, Grindel SH, Lovell MR, Dede DE, Moser DJ, Phalin BR, Nogle S, Wasik M, Cordry D, Daugherty MK, Sears SF, Nicolette G, Indelicato P, McKeag DB: Relationship between concussion and neuropsychological performance in college football players. JAMA 282: 964-970, 1999

8. Collins MW, Lovell MR, Iverson GL, Cantu RC, Maroon JC, Field M: Cumulative effects of concussion in high school athletes. Neurosurgery 51(5):1175-1179, 2002

9. Congress of Neurological Surgeons: Committee on Head Injury Nomenclature: Glossary of head injury. Clin Neurosurg 12:386-394, 1966
10. Crevits L, Hanse MC, Tummers P, Van Maele G: Antisaccades and remembered saccades in mild traumatic brain injury. J Neurol 247: 179-182, 2000

11. DeFord SM, Wilson MS, Rice AC, Clausen T, Rice LK, Barabnova A, Bullock R, Hamm RJ: Repeated mild brain injuries result in cognitive impairment in B6C3F1 mice. J Neurotrauma 19: 427-438, 2002

12. Delaney JS, Lacroix VJ, Leclerc S, et al. : Concussions among university football and soccer players. Clin J Sport Med 12: 331-338, 2002

13. DeRoss AL, Adams JE, Vane DW, Russell SJ, Terella AM, Wald SL: Multiple head injuries in rats: Effects on behavior. J Trauma 2002 52(4):708-714

14. Folkerts MM, Berman RF, Muizelaar JP, Rafols JA: Disruption of MAP-2 immunostaining in rat hippocampus after traumatic brain injury. J Neurotrauma 15(5): 349-363, 1998

15. Gennarelli TA: Mechanisms of brain injury. J Emerg Med 11[Supp 1]:5-11, 1993

16. Gronwall D, Wrightson P: Cumulative effect of concussion. Lancet 2:995-997, 1975

17. Guskiewicz KM, Weaver NL, Padua DA, Garrett WE Jr: Epidemiology of concussion in collegiate and high school football players. Am J Sports Med 28: 643-650, 2000

18. Hovda DA, Yoshino A, Kawamata T, Katayama Y, Becker DP: Diffuse prolonged depression of cerebral oxidative metabolism following concussive brain injury in the rat: A cytochrome oxidase histochemistry study. Brain Res 567:1-10, 1991

19. Hsiang JN, Yeung T, Yu AL, Poon WS: High-risk mild head injury. J Neurosurg 87: 234-238, 1997

20. Huh JW, Laurer HL, Raghupathi R, Helfaer MA, Saatman KE: Rapid loss and partial recovery of neurofilament immunostaining following focal brain injury in mice. Exp Neurol 175(1):198-208, 2002

21. Iverson GL, Gaetz M, Lovell MR, Collins MW:Cumulative effects of concussion in amateur athletes. Brain Inj 18(5): 433-443,2004

22. Jenkins LW, Moszynski K, Lyeth BG, Lewelt W, DeWitt DS, Allen A, Dixon CE, Povlishock JT, Majewski TJ, Clifton G, Young HF, Becker DP, Hayes RL: Increased vulnerability of the mildly traumatized rat brain to cerebral ischemia: The use of controlled secondary ischemia as a research tool to identify common or different mechanisms contributing to mechanical and ischemic brain injury. Brain Res 477:211-224, 1989

23. Johnston KM, McCrory P, Mohtadi NG, Meeuwisse W: Evidence-based review of sport-related concussion: Clinical science. Clin J Sport Med 11: 150-159, 2001

24. Jordan BD. Chronic traumatic brain injury associated with boxing. Semin Neurol 20(2):179-185, 2000

25. Kelly J: Sports-related recurrent brain injuries: United States. JAMA 277:1190-1191, 1997

26. Laurer HL, Bareyre FM, Lee VM, Trojanowski JQ, Longhi L, Hoover RC, Saatman KE, Raghupathi R, Hoshino S, Grady MS, McIntosh TK: Mild head injury increases the brain's vulnerability to a second concussive impact. J Neurosurg 95:859-870, 2001

27. Laurer HL, McIntosh TK: Experimental models of brain trauma. Curr Opin Neurol 12:715-721, 1999

28. Anders Lewén, Gui Lin Lic, Yngve Olssonc, Lars Hillered: Changes in microtubule-associated protein 2 and amyloid precursor protein immunoreactivity following traumatic brain injury in rat: influence of MK-801 treatment. Brain Res Vol. 719, Issues 1-2, 161-171, 1996 
29. Longhi L, Saatman KE, Fujimoto S, Raghupathi R, Meaney DF, Davis J, McMillan B S A, Conte V, Laurer HL, Stein S, Stocchetti $\mathrm{N}$, McIntosh TK: Temporal window of vulnerability to repetitive experimental concussive brain injury. Neurosurgery 56(2):364-374,2005

30. Macciocchi SN, Barth JT, Littlefield L, Cantu RC: Multiple concussions and neuropsychological functioning in collegiate football players. J Athletic Training 36: 303-306, 2001

31. Matser EJ, Kessels AG, Lezak MD, Jordan BD, Troost J: Neuropsychological impairment in amateur soccer players. JAMA 282:971-973, 1999

32. Matser JT, Kessels AG, Lezak MD, Troost J: A dose-response relation of headers and concussions with cognitive impairment in professional soccer players. J Clin Exp Neuropsychol 23(6):770-774,2001

33. Mittl RL, Grossman RI, Hiehle JF, Hurst RW, Kauder DR, Gennarelli TA, Alburger GW: Prevalence of MR evidence of diffuse axonal injury in patients with mild head injury and normal head CT findings. AJNR 15: 1583-1589, 1994

34. Morris R: Developments of a water-maze procedure for studying spatial learning in the rat. J Neurosci Methods 11(1):47-60, 1984
35. Pellman EJ, Viano DC, Casson IR, Casson IR, Tucker AM, Waeckerle JF, Powell JW, Feuer H.: Concussion in professional football: Repeat injuries-part 4. Neurosurgery 55(4):860-873, 2004

36. Quality Standards Subcommittee: Practice parameter: The management of concussion in sports (summary statement)Report of the Quality Standards Subcommittee. Neurology 48:581-585, 1997

37. Weber JT. Experimental models of repetitive brain injuries. Prog Brain Res 161:253-261, 2007

38. Woo BH, Thoidis G: Epidemiology of traumatic brain injury. In: Woo BH and Nesathurai S (Eds.). The Rehabilitation of People with Traumatic Brain Injury. Malden Blackwell Science, 2000: 13-17

39. Yoshino A, Hovda DA, Kawamata T, Katayama Y, Becker DP: Dynamic changes in local cerebral glucose utilization following cerebral concussion in rats: Evidence of hyper and subsequent hypometabolic state. Brain Res 561:106-119, 1991

40. Zanier ER, Lee SM, Vespa PM, Giza CC, Hovda DA: Increased hippocampal CA3 vulnerability to low-level kainic acid following lateral fluid percussion injury. J Neurotrauma 20:409-420, 2003 